\section{Micellar Organisation in Primary Cell Walls}

IN recent $\mathrm{X}$-ray investigations ${ }^{1}$ upon the cell wall organisation of conifer cambium, it was observed that much of the diffuse radiation tending to mask the diffraction diagram of the cellulose could be eliminated by a preliminary extraction of the tissue with pectic solvents or with dilute acid $(0 \cdot 1 \mathrm{~N}$ hydrochloric acid).

In more recent work, using pellets of cambium from Pinus sylvestris, or of the parenchyma of Avena coleoptiles, it has been observed that in the untreated specimens the diffraction rings of $3.9 \mathrm{~A}$. spacing were prominent (Fig. 1), while the 5.4 and $6 \cdot 1$ A. diffraction rings were only faintly visible or absent. Upon extraction with the above reagents, however, the

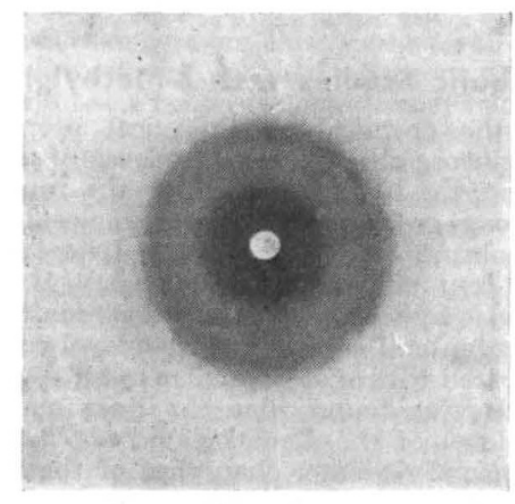

Fig. 1

3.9 A. diffraction ring was considerably sharpened, and additional rings corresponding to spacings of $2.56 \mathrm{~A}$. and $5.5 \mathrm{~A}$. (possibly corresponding to the fused $5 \cdot 4$ and $6 \cdot 1 \mathrm{~A}$. spacings) became apparent (Fig. 2). From measurements of the $3 \cdot 9$ A. spacing at half maximum intensity, the average micelle breadth was calculated, using the Scherrer formula, to be $18 \mathrm{~A}$. in the unextracted tissue and $26 \mathrm{~A}$. after extraction, as compared with a value of $58 \mathrm{~A}$. obtained for ramie under the same conditions. This apparent change in micelle size, taken in conjunction with the appearance of additional diffraction rings upon extraction, would seem to indicate a considerable increase in the crystallinity of the specimen as a result of the extraction treatment, and it is of interest to consider the manner in which this change could have taken place.

The sharpening of the $3.9 \mathrm{~A}$. diffraction ring, coupled with the increased intensity of rings corresponding to planes both parallel and perpendicular to the micelle length, leads to the conclusion that the micelles had increased in both length and breadth as a result of the extraction treatment. An increase in length can be envisaged as arising from the increased orientation of cellulose molecules at the ends of the micelles, upon the removal of extraneous materials from between them; while an increase in breadth could possibly result from the condensation of molecules oriented parallel to the micelle length, but in the untreated tissue separated from the micelle surface by pectin and other cell-wall constituents. Thus, according to this conception, it is assumed that in the natural state the micelles are surrounded by parallel cellulose molecules separated from one another and from the micellar surface by other cell-wall constituents. Such a view would seem to be consistent with the observed diffeulty in obtaining the normal cellulose reactions-for example, with iodine and sulphuric acid-in cambium cell-walls, unless they are subjected to a preliminary acid hydrolysis. Furthermore, if such a view can be considered as extending to secondary cell walls, it may well account for the known difficulty in extracting the last traces of cell-wall constituents such as xylan and lignin ${ }^{2}$, which may be considered as held between the cellulose chains immediately adjacent to the micelles, and may account for dichroism of lignin observed in some tissues $^{3} 4$.

It may also be noted that the recent work of Hessler, Merola and Berkley ${ }^{5}$ has shown in the primary wall of cotton the degree of polymerization of the cellulose

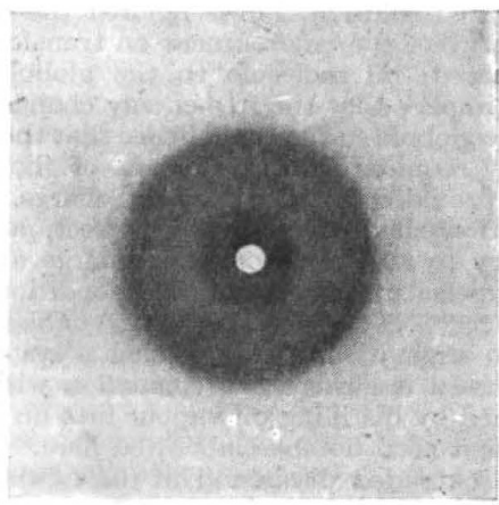

Fig. 2

is 5,940 compared with 10,650 in the secondary wall, and it may be that this difference is related to the smaller micelle size observed in primary cell walls during the present investigation.

Finally, the extremely small micelle size here observed in primary walls is of interest in relation to the recent electron microscopic investigations of Preston et al. ${ }^{6}$ on Valonia and of Frey-Wyssling ${ }^{7}$ on some primary and secondary cell walls. In both these investigations fibrillar strands of cellulose of $250-300 \mathrm{~A}$. in diameter have been observed; but whereas in the case of secondary walls the micelles are 60-70 A. in diameter ${ }^{8}$, in primary walls as shown above they are only about $20 \mathrm{~A}$. in diameter. It would thus appear that the fibrillar strands observed in the electron microscope represent super-micellar units, which possess an approximately constant breadth irrespective of the size of the micelles of which they are composed.

\section{A. B. WARDROP}

Department of Botany, University, Leeds. July 5 .

${ }^{1}$ Preston, R. D., and Wardrop, A. B., Biochim. et Biophys. Acta, 3, 549 (1949),

${ }^{2}$ Wise, L. E., "Wood Chemistry" (Reinhold Corp., N.Y., 1946).

${ }^{3}$ Frey, A., Jahrb. Wiss. Bot., 67, 597 (1927).

Lange, P., Svenska Traforskninginstitutet Meddelande 21 (1947).

${ }^{5}$ Hessler, L. E., Merola, G. V., and Berkley, E. E., T'ext. Res. J., 18, 628 (1948).

- Preston, R. D., Nicolai, E., Reed, R., and Millard, A., Nature, 162, 665 (1948).

${ }^{7}$ Frey-Wyssling, A., Muhlethaler, K., and Wyckoff, R. W. G., Experientia, 4, 12, 475 (1948).

s Hengstenberg, J., and Mark, H., Z. Krist.. 69, 271 (1928). 